\begin{tabular}{|c|c|c|}
\hline 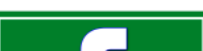 & Int.J.Curr.Microbiol.App.Sci (2021) 10(08): 240-246 & \\
\hline & $\begin{array}{l}\text { International Journal of Current Microbiology and Applied Sciences } \\
\text { ISSN: 2319-7706 Volume } \mathbf{1 0} \text { Number } 08 \mathbf{( 2 0 2 1 )} \\
\text { Journal homepage: } \underline{\text { http://www.ijcmas.com }}\end{array}$ & 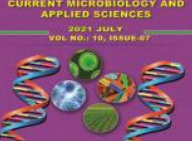 \\
\hline $\begin{array}{l}\text { EXCELLENT } \\
\text { PUBLISHERS }\end{array}$ & & \\
\hline
\end{tabular}

\title{
Field Evaluation of Different Fungicides for their Effectiveness against Phytophthora Blight Disease of Sesame (Sesamum indicum L.)
}

\author{
B. Bora ${ }^{1^{*}}$ and P. Handique ${ }^{2}$ \\ ${ }^{1}$ Department of Plant Pathology, Biswanath College of Agriculture, \\ Biswanath Chariali, Assam-784176, India \\ ${ }^{2}$ KrishiVigyan Kendra, AAU, Lakhimpur, Assam-787001, India \\ *Corresponding author
}

Keywords

Percent disease intensity, phytophthora blight, kharif sesame, fungicide, rainfed

Article Info

Accepted:

15 July 2021

Available Online:

10 August 2021
Sesame (Sesamum indicum L.) is one of the important oilseed crops which are usually grown under rainfed condition on marginal lands in India. In Assam, the crop is grown in different parts of the state during summer and kharif season. The crop sesame is infected by several fungal, bacterial as well as phytoplasma diseases in the field grown in both the seasons, however, the kharif sesame which covers most of the sesame growing areas of the state often encountered by Phytophthora blight(Phytophthora parasitica var. sesame) due to frequent rainfall during the month of August-September which generally coincides with the early growth stage of the crop causing severe mortality of young seedlings as well as leaf blight in standing crops inflicting heavy yield losses. Considering the seriousness of the disease and the importance of the crop, particularly in the Upper Brahmaputra Valley Zone of Assam, an experiment was conducted during 2016-17 and 2017-18 to evaluate the best fungicide against the disease in the field. Fungicides like Matalaxyl + mancozeb, Copper oxychloride, Fosetyl-Al, Mancozeb and Chlorothalonil were tested to evaluate their effectiveness against Phytophthora blight of sesame in the field condition. Out of all the tested fungicides, Matalaxyl + mancozeb $(0.20 \%)$ was found to be the most effective fungicide in reducing highest $(64.17 \%)$ PDI over control followed by Fosetyl-Al $(0.15 \%)$, Copper oxychloride $(0.20 \%)$ and Mancozeb (0.20\%) with $57.75 \%, 49.49 \%$ and $44.84 \%$ reduction of PDI over control, respectively.

\section{Introduction}

Sesame (Sesamum indicum L.) is one of the important oilseed crops usually grown under rainfed condition on marginal lands in India. In Assam sesame is grown both as summer as well as kharif crop. In India it occupies an area of 14.20 lakh hectare accounting production of $6.89 \mathrm{Lakh}$ tone with productivity of $485 \mathrm{~kg} \mathrm{ha}^{-}$ ${ }^{1}$ (Ministry of Agriculture, Govt. of India). In Assam, the crop is grown in an area of 12172 ha with a production of 9232 tonne and productivity of $758 \mathrm{~kg} \mathrm{ha}^{-1}$. Sesame has excellent cooking, medicinal, cosmetic and 
nutritional qualities and its seed is a rich source of oil (50\%) and protein (24\%). Sesame oil primarily contributes olic, linolic, palmitic and steric fatty acids. Productivity of Sesame in India is very low compared to China and Egypt. Among other factors responsible for low productivity, attack of disease is one of the important factors.

The crop sesame is infected by several fungal, bacterial as well as phytoplasma diseases in the field grown in both summer as well as kharif seasons. Out of all the diseases, the Phytophthora blight caused by Phytophthora parasitica var. sesame is an economically important disease appearing in all the sesame grown areas in the country. The kharif sesame which covers most of the sesame growing areas of the state, particularly in the Upper Brahmaputra Valley Zone of Assam often encountered by Phytophthora blight disease due to frequent rainfall during the month of August-September which generally coincides with the early growth stage of the crop causing severe mortality of young seedlings as well as cause leaf blight symptoms in standing crops inflicting heavy yield losses. The disease was first reported from India (Butler, 1918). The disease appears in severe proportion in the states of Gujarat, Madhya Pradesh and Rajasthan, U.P and moderate in Punjab, Haryana, Maharashtra, Andhra Pradesh, Tamil Nadu, West Bengal and Bihar (Verma, 2002, Kale and Prasad, 1957). Singh et al., (1976) reported that the disease may lead to mortality of plants as high as 72 to $79 \%$. The yield loss due to this disease varied from $66.0 \%$ in Gujarat to $79.8 \%$ in Central Madhya Pradesh (Verma et al., 2005).

The disease may occur at any stage of the crop; however, it becomes very serious when infection occurs at the seedling stage and kills the affected plants. The mortality of plants due to this disease may be as high as 72 to $80 \%$ (Singh et al., 2005). It may cause $100 \%$ yield loss when infection occurs at seedling stage under the most favourable conditions.

The initial symptom of the disease appears as water soaked spots on leaves and stems which are chestnut brown in the beginning and later turn into black causing premature leaf fall. The disease becomes sever under continuous rainy days affecting all the aerial parts of plants and covers whole field within few days, main root is affected, diseased plants are easily pulled out and produce shrivelled seeds and gives blighted appearance. The spots are brown in the beginning which later turns to black. Disease can attack at all the stages of the crop (Roy et al., 2007).

Different management practices are used to control plant diseases caused by various pathogens, however, application of chemical fungicides remains to be the first choice for the farmers to manage diseases in different crops because of their easy availability, adaptability and immediate therapy. Fungicides are mostly applied to control different diseases of sesame, including the Phytophthora blight caused by Phytophthora parasitica var. sesame. Kalita et al., (2002) reported that spraying of $0.3 \%$ Fytolan (Copper oxychloride) at 20, 40 and 60 days after sowing effectively controlled the disease and thereby reduced the yield loss.

Gupta et al., (2018) reported that seed treatment with Thiram $(0.2 \%)+$ Carbendazim 50WP $(0.1 \%)$ along with foliar spray with wettable sulphur $(0.2 \%)$ was found most effective to minimize the incidence of powdery mildew. In case of bacterial diseases seed treatment with Streptocycline (250$300 \mathrm{ppm})$ was found to be most effective. Seed treatment with Thiram $(0.2 \%)+$ Carbendazim 50WP $(0.1 \%)$ and two foliar sprays of (Mancozeb 2\%+ Carbendazim1\%) was effective in reducing the Alternaria and Cercospora disease and recorded highest yield. 
Seed treatment with Imidacloprid (@ $5 \mathrm{ml} \mathrm{kg}^{-1}$ seed) followed by foliar spray of Thiomethaxam @0.2 $\mathrm{g} \mathrm{l}^{-1}$ was found effective in reducing the vector population and sesame phyllodydisease incidence.

Ermiasand Dagne (2021) tested several fungicides against Cercospora leaf spot disease of Sesame in Ethiopia. Out of which Tilt $250 \mathrm{EC}$ was found to be the most effective fungicide in controlling the disease with lowest $(5.00 \%)$ disease severity and resulted highest grain yield $\left(618.98 \mathrm{~kg} \mathrm{ha}^{-1}\right)$. Khalifa (1997) also reported that Rizolex-f or Benlate as seed treatment + Chlorneb as soil treatment were found superior for controlling root rot and wilt diseases and increased seed yield of sesame under field conditions

Application of biopesticides has shown encouraging result in managing the Phytophthora blight disease of sesame. Application of Trichoderma viridae, $T$. harzianum and Pseudomonas fluorescens as seed treatment has reduced the disease significantly and increased the yield substantially (Verma, 2002). Seed treatment

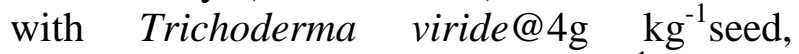
Pseudomonas fluorescens @ $10 \mathrm{gkg}^{-1}$ seed or

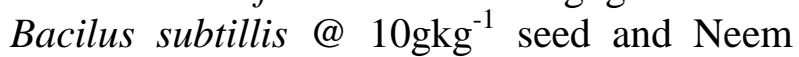
seed kernel extract (NSKE) 5\% was found helpful controlling soil borne pathogens (Augstburger et al., 2000).Gupta et al., (2018) also found that Seed treatment with $T$. viride $\left(5 \mathrm{gkg}^{-1}\right.$ seed and soil application of T. viride @ $2.5 \mathrm{kgha}^{-1}$ was found effective and economical for the management of Macrophomina root /stem rot of sesame.

Cultivation of resistant varieties was also found to be the most effective and cheap method to combat the disease as compared to chemical or biological control (Basavaraj et al., 2009). Mutant varieties resistance to Phytophthora in sesame has been developed in the Republic of Korea (Ashri, 2001) and Sri
Lanka (Bedigian, 2010). In India also, several research workers screened sesame germplasms against powdery mildew disease (Sushama Nema and Duhoon, 2008; Padma Sundari and Kamala, 2012).

Pathirana (1992) screened the induced mutant population of sesame against Phytophthora disease under natural epiphytotic condition. Sesame variety tolerant to Phytophthora blight disease was also developed by Pathirana et al., (2000).

The use of resistant genotypes was a longterm solution to control this problem(Ranganatha et al., 2012).In Korea, a black sesame variety 'Kangheuk' was developed by hybridization followed by pedigree selection with Phytophthora blight resistance and high yielding (Shim et al., 2012). Verma et al., (2005) observed that persistence of continuous rain and humid weather for a longer period during sowing to seedling establishment stage favours the disease. Further, they opined that high humidity for a longer period and temperature range of $25-35^{\circ} \mathrm{C}$ is necessary for disease development but the pathogen failed to grow at temperature above $35^{\circ} \mathrm{C}$. Harilal et al., (2015) screened several sesame entries for field resistance against Phytophthora blight disease under natural epiphytotic conditions and reported that Gujarat Til 10 (GT 10) found superior against Phytophthora blight disease with disease intensity ranging from 3.74 and $5.92 \%$ under high disease presser condition.

The variety GT 10 also showed statistically equal yield performance to other check varieties. Considering the seriousness of the disease and importance of the crop, particularly in the Upper Brahmaputra Valley zone of Assam, the present investigation was made to evaluate the best fungicide in managing the Phytophthora blight disease of sesame under field condition. 


\section{Materials and Methods}

Field Experiment was carried out at farmer's field under Cluster Frontline Demonstration (CFLD) of Krishi Vigyan Kendra, Lakhimpur, Assam, India during the kharif season of 2016-17 and the same experiment was repeated during kharif, 2017-18.The field experiment was conducted in Randomized Block Design (RBD) with six treatments and four replications were maintained for each treatment.

The experimental field was prepared by proper ploughing and harrowing and individual plot of size $8 \times 4 \mathrm{~m}^{2}$ was prepared.

All the agronomic practices as recommended in Package of Practices (Kharif), published jointly by Department of Agriculture, Government of Assam and Assam Agricultural University (AAU), Jorhat were followed. The sesame cultivar Bahuabheti was used for the present investigation. Seeds were sown uniformly in all the plots and the crop was thinned at 15-20 days after germination maintaining a plant to plant distance of $10 \mathrm{~cm}$. Several fungicides viz. Metalaxyl8\%wp + mancozeb 63\%wp (0.20\%), Mancozeb 75\%wp (0.20\%), Fosetyl-Al 80\%wp (0.15\%), Copper oxychloride 50\%wp $(0.20 \%)$ and Chlorothalonil $75 \quad \% \quad$ wp $(0.1 \%)$ were evaluated for their efficacy against the Phytophthora blight disease under field condition. The first spray of these above mentioned fungicides were given immediately after appearance of initial symptoms developed on lower leaves; subsequently two sprays with these fungicides were given at 15 days interval. Leaf infections of Phytophthora blight disease was assessed on randomly selected twenty five plants from each plots under natural conditions after one week of last spray using 0 to 5 rating scale (Rajpurohit, 1993). The Percent Disease Intensity (PDI) was calculated according to Wheeler (1969). The seed yield was also recorded and expressed in $\mathrm{kg} \mathrm{ha}^{-1}$.

$$
\text { PDI }=\frac{\text { Sum of individual rating }}{\text { Total no of leaves examined }} \times \frac{100}{\text { Maximum grade in the rating scale }}
$$

\section{Statistical Data Analysis}

The experimental data collected were analyzed statistically for its significance of difference by the normal statistical procedure adopted for randomized block design and interpretation of data was carried out by OPSTAT package of programs (Sheoran, 2006) after angular transformation. The treatment means were compared by Duncan's Multiple Range Test (DMRT).

\section{Results and Discussion}

The pooled data presented in Table 1 revealed that all the treatments (fungicides) significantly reduced the intensity of Phytophthora blight in sesame. Minimum PDI $(22.32 \%)$ was recorded in matalaxyl + mancozeb $(0.20 \%)$ sprayed plots which was followed by Fosetyl-Al (0.15\%), Copper oxychloride $(0.20 \%)$ and Mancozeb $(0.20 \%)$ treated plots with $26.32 \%, 31.46 \%$ and 34.36 $\%$ PDI, respectively while, Chlorothalonil $(0.20 \%)$ was found least effective against Phytophthora blight of sesame with maximum $(41.52 \%)$ PDI. However, the result of Matalaxyl + mancozeb $(0.20 \%)$ was at par with that of Fosetyl-Al $(0.15 \%)$ in terms of PDI. Likewise, the result of Copper oxychloride $(0.20 \%)$ and Mancozeb $(0.20 \%)$ was also at par in regards to PDI.

Highest reduction(64.17\%) of PDI over control was recorded in the Matalaxyl + mancozeb $(0.20 \%)$ treated plot followed by Fosetyl-Al (0.15\%), Copper oxychloride $(0.20 \%)$ and Mancozeb $(0.20 \%)$ treated plots with $57.75 \%, 49.49 \%$ and $44.84 \%$ reduction of PDI over control, respectively. The lowest reduction $(33.34 \%)$ of PDI over control was observed in Chlorothalonil $(0.20 \%)$ treated plot. 
Table.1 Efficacy of fungicides on disease intensity of Phytophthora blight of sesame.

\begin{tabular}{|c|c|c|c|c|}
\hline \multirow{2}{*}{ Treatments } & \multicolumn{2}{|c|}{ Percent Disease Intensity(PDI) } & $\begin{array}{c}\text { Reduction of PDI } \\
\text { over control (\%) }\end{array}$ \\
\cline { 2 - 5 } & $\mathbf{2 0 1 6 - 1 7}$ & $\mathbf{2 0 1 7 - 1 8}$ & Pooled PDI & \\
\hline $\begin{array}{c}\text { T1= Metalaxyl + } \\
\text { mancozeb }\end{array}$ & $26.18(30.75)^{\mathrm{d}}$ & $18.46(25.37)^{\mathrm{d}}$ & $22.32(28.06)^{\mathrm{d}}$ & 64.17 \\
\hline T2=Copper oxychloride & $34.28(35.82)^{\mathrm{bc}}$ & $28.64(32.32)^{\mathrm{c}}$ & $31.46(34.06)^{\mathrm{c}}$ & 49.49 \\
\hline T3=Fosetyl- Al & $30.28(33.34)^{\mathrm{cd}}$ & $22.36(28.19)^{\mathrm{d}}$ & $26.32(30.74)^{\mathrm{d}}$ & 57.75 \\
\hline T4=Mancozeb & $36.44(37.12)^{\mathrm{b}}$ & $32.28(34.59)^{\mathrm{c}}$ & $34.36(35.84)^{\mathrm{c}}$ & 44.84 \\
\hline T5=Chlorothalonil & $38.68(38.45)^{\mathrm{b}}$ & $44.36(41.75)^{\mathrm{b}}$ & $41.52(40.08)^{\mathrm{b}}$ & 33.34 \\
\hline T6=Control & $60.46(51.05)^{\mathrm{a}}$ & $64.12(53.22)^{\mathrm{a}}$ & $62.29(52.12)^{\mathrm{a}}$ & \\
\hline SEd $\mathbf{C}$ & 1.56 & 1.59 & 1.44 & \\
\hline CD(P=0.05) & 3.35 & 3.43 & 2.97 & \\
\hline
\end{tabular}

Data within parenthesis are angular transformed values

Table.2 Efficacy of different fungicides on seed yield of sesame.

\begin{tabular}{|c|c|c|c|}
\hline \multirow{2}{*}{ Treatments } & \multicolumn{3}{|c|}{ Seed yield (kg ha $\left.\mathbf{~}^{\mathbf{1}}\right)$} \\
\cline { 2 - 4 } & $\mathbf{2 0 1 6 - 1 7}$ & $\mathbf{2 0 1 7 - 1 8}$ & Pooled Yield \\
\hline T1= Metalaxyl + mancozeb & $994^{\mathrm{a}}$ & $984^{\mathrm{a}}$ & $989^{\mathrm{a}}$ \\
\hline T2=Copper oxychloride & $882^{\mathrm{c}}$ & $834^{\mathrm{c}}$ & $858^{\mathrm{c}}$ \\
\hline T3=Fosetyl- Al & $973^{\mathrm{b}}$ & $962^{\mathrm{b}}$ & $967^{\mathrm{b}}$ \\
\hline T4=Mancozeb & $746^{\mathrm{d}}$ & $726^{\mathrm{d}}$ & $736^{\mathrm{d}}$ \\
\hline T5=Chlorothalonil & $638^{\mathrm{e}}$ & $614^{\mathrm{e}}$ & $626^{\mathrm{e}}$ \\
\hline T6=Control & $412^{\mathrm{f}}$ & $394^{\mathrm{f}}$ & $403^{\mathrm{f}}$ \\
\hline SEd \pm & 6.28 & 6.44 & 5.81 \\
\hline CD(P=0.05) & 13.52 & 13.85 & 11.99 \\
\hline
\end{tabular}

The pool data exhibited in the Table 2 showed that the seed yield was also increased in all treatments. Highest meanseed yield was obtained in Metalaxyl+ mancozeb $\left(989 \mathrm{~kg} \mathrm{ha}^{-}\right.$ $\left.{ }^{1}\right)$ treated plot which was followed by FosetylAl $(0.15 \%)$, Copper oxychloride $(0.20 \%)$ and Mancozeb $(0.20 \%)$ treated plots with a seed yield of $967 \mathrm{~kg} \mathrm{ha}^{-1}, 858 \mathrm{~kg} \mathrm{ha}^{-1}$ and $736 \mathrm{~kg} \mathrm{ha}^{-1}$, respectively while, the plot treated with Chlorothalonil $(0.20 \%)$ recorded the least $(626$ $\left.\mathrm{kg} \mathrm{ha}{ }^{-1}\right)$ seed yield. In the present investigation, three sprays of Matalaxyl + mancozeb $(0.20 \%)$, first immediately after appearance of initial symptoms and subsequent two sprays at 15 days interval was found to be the most effective against
Phytophthora blight of sesame. This was in conformity with the findings of Minuto et al.,(2000) who tested several fungicides against Phytophthoranicotianae var parasitica causing root rot disease of lavender, among different fungicides tested, Metalaxyl showed the best efficacy for the control of Phytophthora root rot.

Sharma et al., (1970) tested ten different fungicides among them, Dithan M-45 which was the most economic for control of buckeye rot of tomato caused by Phytophthoranicotianae var parasitica. Farih and Jrifi (1998) also reported that Metalaxyl and Fosetyl- Al effectively control 
Phytophthora citrophthora causing brown rot in citrus. Vyas (1981) reported that application of dithiocarbamate fungicides such as Mancozeb $(0.30 \%)$ or Zineb $(0.30 \%)$ were found effective for the control of Phytophthora blight of sesame.

Application of Matalaxyl + mancozeb $(0.20 \%)$ also increased the seed yield which is due to the reduction of PDI as witnessed in the present investigation which was in conformity with the findings of several other researchers. A mixture of Metalaxyl + mancozeb (0.20\%) applied at 14 and 21days interval in potato crop against Phytophthora infestans, improve yield by 19.8 and $13.11 \%$, respectively (Anonymous, 1979).

Matalaxyl + mancozeb $(0.20 \%)$ was found to be the most effective fungicide against Phytophthora blight of sesame with lowest $(22.32 \%)$ PDI followed by Fosetyl-Al $(0.15 \%)$, Copper oxychloride $(0.20 \%)$ and Mancozeb (0.20\%) with $26.32 \%, 31.46 \%$ and $34.36 \%$ PDI, respectively. Highest mean seed yield (989 $\mathrm{kg} \mathrm{ha}^{-1}$ ) was obtained in Metalaxyl+ mancozeb treated plot followed by Fosetyl-Al, Copper oxychloride and Mancozeb treated plots with a seed yield of967 kg ha ${ }^{-1}, 858 \mathrm{~kg} \mathrm{ha}^{-1}$ and $736 \mathrm{~kg} \mathrm{ha}{ }^{-1}$, respectively.

\section{Acknowledgements}

The authors are thankful to Director of Extension Education, Assam Agricultural University, Jorhat, Assam for providing all the necessary facilities.

\section{References}

Anonymous, 1979. Chemical control of potato blight. Annual report of the West of Scotland Agricultural college for the year ended $30^{\text {th }}$ Sept. $1979,88-89$.

Ashri, A., 2001. Induced mutations in sesame breeding. In: Proceeding of Sesame
Improvement by Induced Mutations. IAEA, Veienna. pp.13-20.

Augstburger. F., Berger, J., Censkowsky, U., Heid, P., Milz, J., Streit, C. Organic cultivation of sesame.First edition, Naturelande.V., Germany 2000.

Basavaraj, S. H., Singh, V. K., Singh, A., Singh, D., Nagarajan, M., Mohapatra, T., Prabhu, K. V., Singh, A. K., 2009. Marker aided improvement of Pusa 6B, the maintainer parent of hybrid Pusa RH10, for resistance to bacterial blight. Indian Journal of Genetics, 69, 10-16.

Bedigian, D., 2010. Sesame: The Genus Sesame. Medicinal and Aromatic Plants- Industrial Profiles Series, Chapter 2. CRC Press, Taylor and Francis Group, Boca Raton.

Butler, E. J., 1918. Fungi and Disease in Plants. Thacker Sprink and Co., Calcutta. 547p.

Ermias Teshome and Dagne Kora, 2021. Field evaluation of different fungicides for their effectiveness against cercospora leaf spot (Cercospora sesame Zimm.) of Sesame (Sesamum indicum L.). Acta Entomology and Zoology: 2(1): 102-107.

Farih, A. and Jrifi, A., 1998. Chemical control of Phytophthora blight of citrus. Alawamia.(96): 41-45.

Gupta, K. N, Naik, K. R., Bisen, R. 2018. Status of sesame diseases and their integrated management using indigenous practices. International Journal of Chemical Studies, 6(2): 1945-1952.

Harilal, J. Kapadiya, Vanrajbhai, N. Gohil, Bachubhai, A. Monpara, 2015. A Black Sesame Variety Gujarat Til 10 (GT 10) Field Resistance to Phytophthora Blight Disease. International Journal of Current Research in Bioscience and Plant Biology, 2(12): 53-63.

Kale, G. H. and Prasad, N., 1957. Phytophthora blight of sesame. Indian Phytopathology. 10:38.

Kalita, M. K., Pathak, K., Barman, U., 2002. Yield loss in sesame due to Phytophthora blight in Barak Valley Zone (BVZ) of Assam. Annals of Biology, 18: 61-62.

Khalifa, M. M. A. Studies of root- rot and wilt disease of sesame plant. M.Sc. Thesis, Faculty of Agriculture, Moshtohor, Zigziguni., Benha Branch.158pp. 1997. 
Minuto, A., Mocioni, M, Gullino, M. I., Garibaldi, A. 2000. Chemical control of Phytophthora nicotianae var. parasitica on pot grown Lavender in Northern Italy. Atti-Giormate-fitopatologiche,-Perugia,16-20 aprile2:329-334.

Padma Sundari, M., Kamala, T., 2012. Screening Sesame indicum L. against powdery mildew. Journal of Basic and Applied Biology, 5: 100-102.

Pathirana, R., 1992. Gamma ray induced field tolerance to Phytophthora blight in sesame. Plant Breeding, 108: 314-319.

Pathirana, R., Weerasena, L. A., Bandara, P., 2000. Development and release of gamma ray induced sesame mutant ANK-S2 in Sri Lanka. Trop. Agric. Res. Ext. 3, 19-24.

Rajpurohit, T. S., 1993. Occurrence, varietal reaction and chemical control of new powdery mildew (Erisipheorontil Cast). Indian Journal of Mycology and Plant Pathology, 23: 207-209.

Ranganatha, A. G. R., Lokesha, R., Tripathi, A., Tabassum, A., Paroha, S., Shrivastava, M. K., 2012. Sesame improvement- Present status and future strategies. Journal of Oilseeds Research, 29: 1-26.

Roy, S. G., Mukherjee, S. K., Somnath, B. 2007. Journal of Mycopathological Research, 45:1:122-128.

Sharma, S. L., Chowfla, S. C., Sohi, H. S., 1970. Chemical control of buckeye rot of tomato. Journal of Mycology and Plant Pathology, 6(2):130-134.

Sheoran, O. P., 2006. Online statistical analysis tool

(OPSTAT).

www.hau.emet.in/about/opstat. php. CCS HAU, Hissar

Shim, K., Kim, D., Park, J., Lee, S., Kim, K., Rho,
J., 2012. A new black sesame variety 'Kangheuk' with lodging and Phytophthora blight disease resistance, and high yielding. Korean Journal of Breeding and Science, 44 :384-387.

Singh, B. P., Shukla, B. N., Kaushul, P. K. 1976. Evaluation of sesame varieties for their susceptibility of Phytophthora parasiticaat Jabalpur. Jawaharlal Nehru Krishi Vishwa Vidyalaya Research Journal 10(1):76.

Singh, R., Singh, U. C., Khare, R. K., Sharma, B. L., 2005. Disease of linseed and sesame and their management. In: Diseases of Field Crops (Ed.: Third, T.D.). Daya Publishing House, New Delhi. pp.135154.

Sushma Nema, Duhoon, S. S., 2008. Field screening of extant varieties of sesame, Sesamum indicum L. against powdery mildew disease. Journal of Oilseeds Research, 25:114-115.

Verma, M. L., 2002. Fungal and bacterial diseases of sesame and their managementChallenges for the millennium. (Ed.: Prasad, D., Puri, S. N.). Jyoty Pub., New Delhi. pp.161-192.

Verma, M. L., Mehta, M., Sangwan, M. S., 2005. Fungal and bacterial diseases of sesame. In: Diseases of Oilseed Crops (Eds.: Salaran, G. S., Mehta, M., Sangwan M.S.). Indus Publishing Co., New Delhi. pp.269303.

Vyas, S. C., 1981. Disease of sesame and niger in India and their control. Pesticides.15(9): 10-15.

Wheeler, B. E. J., 1969. An Introduction to Plant Diseases. John Wiley and Sons Ltd., London. 301p.

\section{How to cite this article:}

Bora, B. and Handique, P. 2021. Field Evaluation of Different Fungicides for their Effectiveness against Phytophthora Blight Disease of Sesame (Sesamum indicum L.). Int.J.Curr.Microbiol.App.Sci. 10(08): 240-246. doi: https://doi.org/10.20546/ijcmas.2021.1008.028 